\title{
Letter to the Editor in regard to the "Effects of COVID-19 on in-hospital cardiac arrest: incidence, causes, and outcome" by Roedl et al."
}

\author{
A. D. Krieg ${ }^{1 *}$, J. Duval-Arnould ${ }^{1}$, H. Newton ${ }^{2}$, B. D. Winters ${ }^{3}$ and E. A. Hunt ${ }^{3}$
}

Dear Editor,

We have read the retrospective article entitled "Effects of COVID-19 on in-hospital cardiac arrest: incidence, causes, and outcome" by Roedl et al. published in the Scandinavian Journal of Trauma, Resuscitation and Emergency Medicine (2021; 29(30)). We want to commend the authors for this informative study and make some contributions.

In the study results, sustained return of spontaneous circulation (ROSC) was defined as stable circulation for at least $20 \mathrm{~min}$. Moreover, the rates of sustained ROSC were comparable across the two study periods (2019 Non-COVID-19 period: 77\% vs. 2020 COVID-19 period: 83\%) [1]. These rates hint at similar outcomes across the study periods; however, the survival rates to discharge from hospital during the Non-COVID-19 period and COVID-19 period, particularly the rates of the survival of the COVID-19 positive subcohort, would provide valuable clinical data. A study collecting retrospective data from a public New York hospital during similar time periods (Non-COVID-19 period: March 1st, 2019 to May 15th, 2019; COVID-19 period: March 1st, 2020 to May 15th, 2020) reported a lower ROSC during the COVID-19 period compared to the Non-COVID-19 period (36\% vs. 56\%) [2]. This outcome correlated to a significantly lower survival to hospital discharge during

*Correspondence: akrieg1@jhu.eduk.roedl@uke.de

${ }^{1} 1600$ North Wolfe Street, Baltimore, MD 21287, USA

Full list of author information is available at the end of the article

E. A. Hunt considered as senior author the COVID-19 period (3\% vs. 13\%). Additionally, survival among COVID-19 patients experiencing IHCA was even lower (2\%).

As we finalize and prepare to publish our analysis of the impact of the COVID-19 pandemic on cardiac arrest survival rates within our institution, we believe that data on the survival to discharge from Roedl's cohort would be invaluable for both comparative reasons as well as to better characterize the effect of sars-cov2 on overall resuscitation success. To this end, we respectfully request that both survival to discharge and 30-day survival from the Roedl study be published as an addendum or otherwise be made available.

\section{Response-Letter to the Editor in regard to the "Effects of COVID-19 on in-hospital cardiac arrest: incidence, causes, and outcome" by Roedl et al."}

\section{Kevin Roed ${ }^{4^{*}}$}

\section{*Correspondence: roedl@uke.de \\ ${ }^{4}$ Department of Intensive Care Medicine, University Medical Centre Hamburg-Eppendorf, Martinistraße 52, 20246 Hamburg, Germany}

To the Editor,

We thank Krieg et al. for the interest in our study and for their valuable comments. We agree with Krieg et al. that both study periods provided an almost similar rate of return of spontaneous circulation (ROSC) (2019: 77\% vs. 2020: $83 \%, p=0.237)$ [3]. In our cohort $40 / 84(48 \%)$ and 34/93 (37\%) were discharged alive from hospital in the 2019 and 2020 period $(p=0.551)$, respectively. original author(s) and the source, provide a link to the Creative Commons licence, and indicate if changes were made. The images or other third party material in this article are included in the article's Creative Commons licence, unless indicated otherwise in a credit line to the material. If material is not included in the article's Creative Commons licence and your intended use is not permitted by statutory regulation or exceeds the permitted use, you will need to obtain permission directly from the copyright holder. To view a copy of this licence, visit http://creativecommons.org/licenses/by/4.0/. The Creative Commons Public Domain Dedication waiver (http://creativecommons.org/publicdomain/zero/1.0/) applies to the data made available in this article, unless otherwise stated in a credit line to the data. 
Furthermore 26/40 (65\%) and 27/34 (79\%) had a favourable neurological outcome at ICU discharge in the 2019 and 2020 period, respectively. According the small subcohort of twelve patients with COVID-19 we can report that $6 / 12(50 \%)$ of patients survived to hospital discharge, $5 / 6$ had favourable neurological outcome. Due to the retrospective nature of our study, we are only able to report on patient survival till hospital discharge.

Although, ROSC rates hint a similar outcome we observed differences in rates to hospital discharge across the two study periods. This may be attributable to the location of cardiac arrest which shifted more towards the ICU in the 2020 period. Cardiac arrest occurring in the ICU shows clinically important differences compared to cardiac arrest occurring in a general ward $[4,5]$. Due to this significant shift in location of cardiac arrest within the two study periods conclusion regarding outcome should be drawn cautious and ROSC may not present the most reliable indicator for survival to hospital discharge.

\section{Abbreviations}

COVID-19: Coronavirus disease 2019; ICU: Intensive care unit; ROSC: Return of spontaneous circulation.

\section{Acknowledgements}

Not applicable.

\section{Authors' contributions}

$\mathrm{HN}, \mathrm{EAH}, \mathrm{JDA}$, and BW all sorted through literature to find this paper and the referenced data. $\mathrm{HN}, \mathrm{EAH}, \mathrm{JDA}$, and $\mathrm{BW}$ also provided edits to produce a concise and clear letter to the editor. ADK analyzed the papers and wrote the letter to the editor requesting data to provide more continuity in the literature. All authors read and approved the final manuscript. KR participated in study conception and design, was involved in acquisition of data. KR contributed to analysis and interpretation of data. KR drafted the manuscript. KR was involved in critical revision of the manuscript for important intellectual content. KR participated in supervision. All authors read and approved the final manuscript.

\section{Funding}

None.

\section{Availability of data and materials}

Data cited in the above letter to the editor can be found in the original paper by Roedl et al. (https://doi.org/10.1186/s13049-021-00846-w) or in the second source by Miles et al. (https://doi.org/10.1161/CIRCOUTCOMES.120.007303). The datasets supporting the conclusions of this article are included within the article.

\section{Declarations}

\section{Ethics approval and consent to participate}

Not applicable. The Ethics Committee of the Hamburg Chamber of Physicians was informed about the study (No.: WF-152/20). The requirement for informed patient consent was waived due to the use of anonymized data from routine clinical care only. The study was approved by the local clinical institutional review board and complied with the Declaration of Helsinki.

\section{Consent for publication}

Not applicable.

\section{Competing interests}

The authors declare that they have no competing interests. KR does not report any conflicts of interest related to this article.

\section{Author details}

${ }^{1} 1600$ North Wolfe Street, Baltimore, MD 21287, USA. ${ }^{2} 550$ N Broadway Ste 401, Baltimore, MD 21205, USA. ${ }^{3} 1800$ Orleans St. Sheikh Zayed Tower, Baltimore, MD 21287, USA.

Received: 19 August 2021 Accepted: 5 October 2021

Published online: 03 November 2021

\section{References}

1. Roedl K, Söffker G, Fischer D, et al. Effects of COVID-19 on in-hospital cardiac arrest: incidence, causes, and outcome-a retrospective cohort study. Scand J Trauma Resusc Emerg Med. 2021;29:30. https://doi.org/10. 1186/s13049-021-00846-w.

2. Miles J, Mejia M, Rios S, et al. Characteristics and outcomes of in-hospital cardiac arrest events during the COVID-19 pandemic. Circ CardiovasC Qual Outcomes 2020;13(11):e007303. https://doi.org/10.1161/CIRCO UTCOMES.120.007303.

3. Roedl K, Söffker G, Fischer D, Müller J, Westermann D, Issleib M, et al. Effects of COVID-19 on in-hospital cardiac arrest: incidence, causes, and outcome - a retrospective cohort study. Scand J Trauma Resuscit Emerg Med. 2021:29:30.

4. Roedl K, Jarczak D, Blohm R, Winterland S, Müller J, Fuhrmann V, et al. Epidemiology of intensive care unit cardiac arrest: characteristics, comorbidities, and post-cardiac arrest organ failure-a prospective observational study. Resuscitation. 2020;156:92-8.

5. Leloup M, Briatte I, Langlois A, Cariou A, Lesieur O, group As. Unexpected cardiac arrests occurring inside the ICU: outcomes of a French prospective multicenter study. Intensive Care Med. 2020;46:1005-15.

\section{Publisher's Note}

Springer Nature remains neutral with regard to jurisdictional claims in published maps and institutional affiliations.

Ready to submit your research? Choose BMC and benefit from:

- fast, convenient online submission

- thorough peer review by experienced researchers in your field

- rapid publication on acceptance

- support for research data, including large and complex data types

- gold Open Access which fosters wider collaboration and increased citations

- maximum visibility for your research: over 100M website views per year

At $\mathrm{BMC}$, research is always in progress.

Learn more biomedcentral.com/submissions 